\title{
Negotiating Ideas: The Communicative Constitution of Pietist Theology within the Lutheran Church
}

\author{
Martin Gierl
}

\begin{abstract}
In this chapter the emergence of enlightened religion is approached from the angle of the form rather than the content of religious communication. Here I analyze the communicative space in which religion was discussed and show how theological controversy, an essential element of the confessional religion of the seventeenth century, developed into new genres and media, ultimately changing not only the shape and tone of the conversation but its content as well. Taking the Pietist controversies in Germany as an example, I show how theological controversy worked and how it enabled innovation while maintaining orthodoxy. As this controversy unfolded in the 1690 s the entire apparatus of the confessional church in Brandenburg became involved in the restoration of ecclesiastical peace. Yet the net result of these efforts was the formulation of an alternative, Pietist theology against an orthodox Lutheran one. Each party proved capable of finding its system supported by Scripture and started to propagate its views in the then-modern medium of scholarly journals devoted to partisan biblical exegesis. These journals were aimed at a theologically interested popular audience and appealed to its 'impartial' judgment. The new, critical approach to the Bible and traditional theology resulting from the Pietist controversies was thus successfully popularized, eventually superseding the confessional orientation. In a subsequent phase, the newly emerging discipline of church history and the eighteenth-century encyclopedias canonized and consolidated Enlightened approaches to religion and piety. Ironically, both genres perpetuated elements drawn from the technique of controversy. The introduction of new media genres thus forced a certain measure of libertas philosophandi upon the Lutheran church. They created church identity in new ways, but also meshed with the Enlightened values of impartiality and improvement and with new means of knowledge production.
\end{abstract}

(C) MARTIN GIERL, 2019 | DOI:10.1163/9789004389397_006

This is an open access chapter distributed under the terms of the prevailing CC-BY-NC License at the time of publication. 
Unavoidably, ideas are not only the outcome of thinking. They are constructed and answer problems that arise within the institutional setting they belong to. Modeled within the medial and institutional frameworks of debates and discourses, they are much more worked-out than thought-out. The constructive nature of ideas has three consequences. It makes the ideas dependent on communication: media formats, analytical methods, and all the complications connected with the public sphere. Second, it makes the ideas dependent on their social background: that is, all kind of interests and regulations triggering their reception, popularity, or rejection. Third, it links the success of a message with the success of the means of its propagation, which often leads to quite unexpected results.

Pietism and Pietist theology are good examples of this phenomenon. The harder Pietists tried to enshrine the Word of God in Christians' hearts by producing a vast spectrum of devotional literature, as well as a growing number of revised, painstakingly commented-on, mass-produced translations of the Bible, the more they instigated reading, writing, individual judgment, even critical analysis and a rapid expansion of the literary market. ${ }^{2}$ Pietism in the narrower sense, that is in the sense of a groundbreaking movement and not only in the sense of a religious strand, existed exactly as long as the propagation of Pietism coincided with the employment of the then-leading tools and institutions to process information. Seen from the communicational side, the Pietist movement consisted of international and interconfessional networks of correspondence; journals; the organization of educational institutions; and the foundation of societies, associations, communities, and settlements. These all steadily proclaimed the message to the world: Pietism exists, Pietism is active, Pietism possesses a structure, a membership, and a coherent identity, as well as a certain diversity and plurality. ${ }^{3}$

Transforming religious drives into communicational tools and organization models, Pietism evolved from the field of Enlightenment and simultaneously

1 My thanks go to Jo Spaans and Jetze Touber for all the work they invested in this article.

2 See Jonathan Sheehan, The Enlightenment Bible: Translation, Scholarship, Culture (Princeton, 2005). On the recent interest in religion and Enlightenment, see: Dmitri Levitin, 'Historiographical Review: From Sacred History to the History of Religion: Paganism, Judaism, and Christianity in European Historiography from Reformation to 'Enlightenment," Historical Journal 55, no. 4 (2012), 1117-6o; Simon Grote, 'Review Essay: Religion and Enlightenment,' Journal of the History of Ideas 75, no. 1 (2014), 137-60.

3 A comprehensive overview on Pietism procures: H. Shantz, An Introduction to German Pietism: Protestant Renewal at the Dawn of Modern Europe (Baltimore, 2013), and H. Shantz, ed., A Companion to German Pietism (Leiden, 2015). 
developed that field. Debates within the German-speaking public sphere of the eighteenth century had to take pietistic stances into account, and that is why, to a certain extent, the German Enlightenment took on its religiously idealistic, romantic, and mystical as well as its discipline- and order-loving flavor. The concept of Wiedergeburt (rebirth) developed into Mündigkeit (maturity), praxis pietatis produced Gebrauch der Verstandeskräfte (use of the power of reason), and it is probably the best Pietist joke of the German Enlightenment (if there are Pietist jokes) that Kant's dictum on "man's emergence from his self-imposed immaturity," rooted deeply in the Pietist tradition, became the globally accepted textbook definition of Enlightenment.

But how did Pietist theology evolve in the first place? Quite interestingly, Pietism did not emerge from a pre-existing Pietist theology. Rather, it first channelled the religious needs and drives of the day into a commonly shared maxim. Pietists stated that true Christianity requires and is equal to the permanently deepened and expressed love of Christ. This maxim rallied people to engage in pious practice, which in turn led to the formation of organized groups. A movement in the making activated the official theologians of the Lutheran church. An immensely intense controversy arose. It was in the wake of this controversy that Pietist theology took shape.

In this chapter, I would like to illustrate one phenomenon in particular. Theological controversy, as it had been institutionalized within the Lutheran church, was no free discourse - even by the low standards of the possibility of free discourses in the first place. Theological controversy was a highly regulated process, which combined theological argumentation with the regulated forms of academic disputations and legal procedures. Universities, Konsistorien (regional bodies of church government), and Ministerien (local committees of the ministers) - that is, the leading church institutions-provided its techniques, structured its battlefield, and were obliged to interfere as much as possible. Theological controversy was anything but an arbitrary wrangling. It was a highly regulated process on several levels at once: social, institutional, and textual. The orthodox clergy were the guardians of the rules and had the power to activate them and oversee their practice. Thus is why Pietist theology was not defined by the Pietists themselves but, to a very large extent, by their orthodox opponents. The orthodox side formulated the questions that the Pietists had to answer. Theological controversy was a coherent apparatus with one crucial aim: to guarantee confessional identity. It was set up to monitor newly developed religious positions and practices and to bring them into the form of a theological dispute in order to test which of these new positions matched the confessional dogma and which did not, and to expel the latter ones so as to re-establish orthodoxy. Deviating forms of piety were systematically translated into dogmatic idiom and thus theologically categorized. 
Heterodoxy was thereby pinned down. ${ }^{4}$ To a remarkable extent, theological controversy resembled modern football or car racing. Both are organized businesses, entirely conducted institutionally and practically through professional agents, referees, official training camps, and regulated performances staged in front of a highly interested audience. But there is one big difference: while football and car racing remain relatively constant over time, with only slight innovations in the way the sport is to be performed, the definition of religious truth in the Pietist controversy changed its media as well as its communicative practices during the run of the game. A culture of pamphlets and disputations became a culture of journals and historiographical textbooks. The defense of dogma became Enlightenment. These changes invited an enlarged circle of supporters to take part in the match.

I divide my argument into three parts: 1 . How theological controversy functioned. 2. How Pietist theology emerged from the Pietist controversy. 3. How theological controversy became ecclesiastical history and, as such, contributed to the basic structures of the new, up-and-coming Enlightened historiography.

\section{How Theological Controversy Functioned}

In the seventeenth century, attempts to safeguard confessional doctrine dominated the theological institutions - the universities, consistories, and ministries. To defend orthodox doctrine was an official duty of the clergy. Controversial theology commanded media in the forms of the pulpit and the pamphlet. The controversialist was the highest-ranking professor at the universities, which taught the technique of disputation as one of their foremost tasks.

The objective of theological controversy was laid down in both positive and negative terms. Positive: to uphold the true doctrine; negative: to ascertain heretical doctrine and to isolate its champions from the church. According to Gratian's law, one had to identify heretics by furnishing evidence of heretical teaching and, moreover, by proving that such heretics obstinately persevered in their heterodoxy. ${ }^{5}$ The former was achieved by argument, the latter demonstrated by the reactions of the accused. Formal proceedings in theological controversies were based on the well-known and much-quoted dictum from

4 In detail: Martin Gierl, Pietismus und Aufklärung: Theologische Polemik und die Kommunikationsreform der Wissenschaft am Ende des 17. Jahrhunderts (Göttingen, 1997).

5 Winfried Trusen, 'Rechtliche Grundlagen des Häresiebegriffs und des Ketzerverfahrens,' in: Ketzerverfolgung im 16. und frühen 17. Jahrhundert [Wolfenbütteler Forschungen 51], ed. Silvana Seidel Menchi et al. (Wiesbaden, 1992), pp. 1-20, there p. 3; Anders Winroth, The Making of Gratian's Decretum (New York, 2009). 
the gospel of Matthew (Matt. 18,15): "If your brother sins, take him to task. If he won't listen, admonish him with witnesses. If he still won't listen, then take the matter to the parish. If that still doesn't work, he is like a heathen and tax collector to you." This passage defined the stages of escalation in a dispute: private warning, rebuke in the presence of witnesses, and public reprimand. This text from Matthew furnished churches with a guideline for ecclesiastical discipline. It was part of most of the Lutheran church ordinances and was enforced by church officials. ${ }^{6}$

There were also more specific rules for theological controversy, pertaining to the techniques and lines of argumentation. Three things were important: complete refutation as a fundamental precept of the approach; syllogistic deduction as an argumentation technique; and church dogma as guidelines for living according to the rules of one's faith.

To start with the second: syllogistic deduction breaks down statements into premises and draws conclusions from them. This makes syllogistic deduction the perfect tool for academic disputation, where a consensus is undermined by a contentious opinion but is reinstated at the close of the argumentation. ${ }^{7}$ Church dogma was the instrument for identifying heretical beliefs and those who denied the teachings of the church. Each article of the authoritative Lutheran Formula of Concord emphatically began "We believe, teach and confess." ${ }^{8}$ The application of syllogisms and the axioms of faith in the attack on perceived heterodoxies functioned like a well-oiled polemical machine. From there the controversy followed an inherent logic. To achieve victory, the accusing party had to launch an attack not only against a selection of the opponent's offending points of view, but also against the supposedly heretical teaching in its entirety. On the other side, the party thus attacked had to defend not only specific points of the attacks but all its details.

Accordingly, theological controversy evolved as a chain of interrelated pamphlets that mutually referred to one another. This was clearly indicated in the pamphlet titles. In 1690 the Hamburg church ministry published a tract against

6 For sources Gierl, Pietismus (see above, n. 3), pp. 78-81.

7 On the Aristotelian tradition of syllogism see Marko Malink, Aristotle's Modal Syllogistic (Cambridge, Mass., 2013); on disputatio and theology see Uwe Gerber, Disputatio als Sprache des Glaubens (Zurich, 1970); on the development of disputations, Kevin Chang, 'From Oral Disputation to Written Text: The Transformation of the Dissertation in Early Modern Europe,' History of Universities 2 (2004), 129-87; as contemporary introduction, Jakob Thomasius, 'De processus disputandi,' in: M. Jacobi Thomasii Erotemata logica pro incipientibus (Leipzig, 1670).

8 See Robert Kolb and James A. Nestingen, eds., Sources and Contexts of the Book of Concord (Minneapolis, 2001); Robert Kolb and Timothy J. Wengert, eds., The Book of Concord: The Confessions of the Evangelical Lutheran Church (Minneapolis, 200o); Irene Dingel et al., Die Bekenntnisschriften der evangelisch-lutherischen Kirche: Quellen und Materialen, Bd. 2: Die Konkordienformel (Göttingen, 2014). 
Spener entitled Abgenöthigte Schutz-Schrifft [Coerced Defense Pamphlet]. ${ }^{9}$ Spener replied with Die Freyheit der Gläubigen ... in gründlicher Beantwortung der so genanndten Abgenöthigten Schutz-Schrift [The Freedom of Believers ... in a Thorough Reply to the Coerced Defense Pamphlet]. The opposition retaliated with Mißbrauch der Freyheit der Gläubigen ... aus Hn. D. Philipp Jacob Speners ... Freyheit der Gläubigen ... gezeiget [Abuse of Freedom Shown by Spener's Freedom of Believers], upon which Spener answered with Sieg der Wahrheit und Unschuld, gezeiget in gründlicher Beantwortung Hn. Joh. Fridrich Mayers ... Mißbrauch der Freyheit der Gläubigen [Victory of Truth in a Thorough Reply of Joh. Fridrich Mayer's Abuse of Freedom].$^{10}$ Each text by the opposition was exhaustively rebutted by a text of one's own: paragraph after paragraph, even sentence after sentence. Refutation meant controverting a specific text down to the last detail. The counter-pamphlet engulfed the initial pamphlet and expanded the discussion by relentlessly pursuing the cycle of answers and rebuttals as prescribed by the rules of engagement. Each individual pamphlet in the exchange is neither an independent unit nor an expression of an individual opinion; it is part of the greater controversy.

Theological controversy was a rule-bound process conducted 'text against text.' Simultaneously it involved disputes of 'man against man.' Both orthodox and Pietist sides recognized the formal precepts of the culture of refutation and censured those who did not comply. Not just anyone could enter the fray; nor was it permitted to dispute with just anyone. But one was, however, strictly obliged to personally defend oneself if one's opponent was of the same standing. If one had seven opponents, one had to reply with seven written apologias - a task one could delegate, but only under certain circumstances. To advocate a position meant having to find comrades-in-arms in numbers reflecting the sensation caused by one's contention. In this way, opinions were disputed with an intensity commensurate to the interest they aroused.11

$9 \quad$ [Johann Friedrich Mayer], Abgenöthigte Schutz-Schrifft. Worinnen wider die harte und ungegründete Beschuldigungen Herrn D. Philipp Jacob Spener \&cc.\&c. Ihren Revers und Religions-Eifer verthädiget das Ministerium in Hamburg (s.l., s.a.).

10 Philipp Jakob Spener, Die Freyheit der Gläubigen ... in gründlicher Beantwortung der so genanndten Abgenöthigten Schutz-Schrift, welche im Namen deß Evangelischen Hamburgischen Ministerii von Herrn D. Johann Friedrich Meyern außgefertiget worden (Frankfurt am Main, 1691); Johann Friedrich Mayer, Mißbrauch der Freyheit der Gläubigen zum Deckel der Boßheit aus Hn. D. Philipp Jacob Speners ... Freyheit der Gläubigen ... gezeiget (s.l., 1692); Philipp Jakob Spener, Sieg der Wahrheit und Unschuld, gezeiget in gründlicher Beantwortung Hn. Joh. Fridrich Mayers ... Mißbrauch der Freyheit der Gläubigen zum Deckel der Boßheit (Cölln an der Spree, 1692). 
Taken together, the institutional, social, communicative, and (con)textual implications of theological controversy enabled the incorporation, through a regulated process, of the individual, ever-changing interests within the clergy into the body of theological learning and teaching. Theological controversy was the instrument that maintained the authority of revelation and church dogma, yet allowed the adaptation of beliefs to the changing demands of the church. The preservation of true doctrine ensured continuity between tradition and innovation in the church. It guaranteed doctrinal identity. So much for the theory.

\section{How Pietist Theology Emerged from the Pietist Controversy}

Between 1690 and 1720, somewhere around five hundred combatants exchanged some two thousand pamphlets on Pietism. The entire clergy took part in the controversy, actively or passively. The Pietist controversy developed in three phases: 1. The compilation of accusations. 2. The systematization and theologization of the controversy. 3. The historicization of the controversy. The Pietist controversy originated in a cluster of extremely vague accusations. The accusers took aim at the Pietist assemblies that had arisen from a desire for a more communally practiced piety, the conventicles, which had been held since 1670 by Spener in Frankfurt. It was alleged, very generally but ominously, that "something was happening"; women would rush there and preach, and even artisans took part. There were rumors about sexual excesses. These rumors led to inquiries and the inquiries to apologias. This in turn prompted Spener's famous Pia Desideria and his tract Das Geistliche Priesterthum [The Spiritual Priesthood] in the mid-1670s. ${ }^{12}$ Both texts justified the conventicles. Spener's justification based their legitimacy on New Testament tradition and the contemporary flaws of the Lutheran church, which, it was claimed, did not deserve the name of 'Evangelical' it had arrogated. Spener argued that the Evangelical inspiration was losing ground in the Lutheran church. In his eyes it needed less disputation and more piety. The conventicles were one way to achieve this purpose. As the spiritual priesthood of all believers was an element of Evangelical doctrine, Spener considered conventicles to be permissible.

The orthodox side also took a stand. Queries on the part of the authorities had led to theological reports. One of the first was compiled in 1678 by the

12 Philipp Jakob Spener, Pia Desideria oder hertzliches Verlangen, nach Gottgefälliger Besserung der wahren Evangelischen Kirchen (Frankfurt am Main, 1676); idem, Das Geistliche Priesterthum (Frankfurt am Main, 1676). 
Darmstadt superintendent Balthasar Mentzer against the local conventicle. Accusingly, it stated that the new religious movement valued 'good deeds' over church dogma; that it denied the authority of the church and rejected the theology of the universities; and above all that it called for a general priesthood and the establishment of conventicles. Mentzer saw the danger of a schism in the making. ${ }^{13}$

At about the same time the term 'Pietists' began to circulate. Thus, both subjects of discussion and a common denominator emerged from the new practice of piety. The subjects of discussion were a) the autonomous practice of piety in the conventicles, outside the bounds of congregational worship; $b$ ) the explicit or implicit criticism of the church that had become associated with these forms of piety; and c) the concomitant softening of church dogma. The outline of a principal danger was located. The clergy was pushed into alarm mode. But there was not yet a clearly delineated Pietist movement intense enough to trigger a general controversy.

A decade later, young Pietist theologians held collegia pietatis at the University of Leipzig, with overwhelming success. ${ }^{14}$ The professors reacted with concern and jealousy. The pamphlet war began and with it the theologization of Pietism. Several critical commentaries were published. Next, the pamphlet Unfug der Pietisten [Mischief of the Pietists], portraying the Pietists as a homogeneous group, found twenty major objections to Pietism and made Spener the man to blame. ${ }^{15}$ Pietism, the charge went, is not just a position within the Lutheran church but a sect. No fewer than thirteen counter-pamphlets from the Pietist side followed. ${ }^{16}$ The theological faculty of Wittenberg took the next step. Together its members pored over Spener's complete works and found 284 doctrinal deviations. Spener painstakingly replied to the strongly orthodox pamphlet, which ran to more than two hundred pages. In more than three hundred pages of his own, he set forth why his doctrine corresponded to church dogma point by point. ${ }^{17}$ Thus emerged the corpus of Pietist theology.

13 Balthasar Mentzer, Kurtzes Bedencken von den Eintzelen Zusammenkunfften, wie dieselbe etlicher Orten wollen behauptet werden (Gießen, 1691), pp. 8-17.

14 Ryoko Mori, 'The Conventicle Piety of the Radicals,' in: A Companion to German Pietism, ed. Douglas Shantz (Leiden, 2015), pp. 201-24; Christian Peters, “'Daraus der Lärm des Pietismus entstanden": Die Leipziger Unruhen von 1689/169o und ihre Deutung durch Spener und die hallischen Pietisten,' Pietismus und Neuzeit 23 (1997), 103-51; Hans Leube, 'Die Geschichte der pietistischen Bewegung in Leipzig,' in: Orthodoxie und Pietismus: Gesammelte Studien von Hans Leube, ed. Dietrich Blaufuß (Bielefeld, 1976), pp. 153-267.

15 Ausführliche Beschreibung des Unfugs welchen die Pietisten ... gestifftet (s.l., 1693), pp. 27-33.

16 Gierl, Pietismus (see above, n. 3), pp. 148-53.

17 Christ-Lutherische Vorstellung, In deutlichen Auffrichtigen Lehr-Sätzen, Nach Gottes Wort, und den Symbolischen Kirchen-Büchern, sonderlich der Augspurgischen Confession, und Unrichtigen Gegen-Sätzen, Aus Herrn D. Philippi Jacobi Speners Schrifften (Wittenberg, 
A spate of smaller controversies ensued, specifying key standpoints. The Pietist demand for a life-determining, heartfelt belief in Christ was discussed in terms of justification, sanctification, the limits of God's mercy, and the essence of the sacraments. Over the course of this debate, a system of Pietist theology took shape that negotiated its 'principium cognoscendi, 'finis, 'subjectum,' and 'media.'18 Justification, sanctification, Christology, grace, and other key concepts of theology could now be used to measure the praxis pietatis. Pietism received a theological face. The Lutheran church, on the other side, was given specified directives with which to measure the orthodoxy of this Pietist theological face. The upshot: there is a 'good' pietism within the church, in contrast to that of radical groups, from which one should distance oneself. Pietists accepted church dogma as the touchstone for the definition of orthodoxy; but they considered heretical not the person who upholds errors, but the person who upholds fundamental errors. To achieve a truly holy life is not possible but is a necessary aspiration. Good deeds cannot redeem a believer, but striving for a pious world in the here and now should be pleasing in the sight of God. The Bible remains the measure of belief, but piety must be the approach to understand the Word of God. The church and its dogma may not remain aims in and of themselves; rather, they exist to disseminate and deepen Christianity. In other words: they shifted the focus of the Lutheran church away from dogma and its defense and toward individual conviction and its profession.

Conviction and its profession were anything but new: they had been central aspects of Christianity since the Apostolic Age, evident in Paul's mission, Boniface's conversion of the Germanic barbarians, Bernard of Clairvaux's merger of knighthood and Christendom, and the Jesuits' obedience to God and his worldly representative. But the question was: How to reconcile the psychological and individual side of this demand with its social and organizational side?

A radically subjective conception - in its psychological as well as individual dimension - of conviction and its permanent profession had been at the center of Johann Arndt's definition of "true Christianity," which he propagated in endless repetitions in his devotional treaty Die vier Bücher vom wahren Christenthum [Four Books on True Christianity, 1610]. This became the most widely owned book after the Bible in the German lands. Some three hundred editions were published up through the end of the nineteenth century. ${ }^{19}$ Arndt

1695); Philipp Jakob Spener, Aufrichtige Übereinstimmung mit der Augsp. Confession, Zu nöthiger Vertheidigung seiner reinen Lehr, von ihm selbst entgegen gesetzt der so genannten Christ-Lutherischen Vorstellung (Frankfurt am Main, 1695).

18 Ausführliche Beschreibung des Unfugs (see above, n. 14), p. 27.

19 Thomas Ilg, Ein anderer Mensch werden:Johann Arndts Verständnis der imitatio Christi als Anleitung zu einem wahren Christentum (Göttingen, 2011), pp. 15-6. 
argued for the killing of the old Adam. True Christianity demands that one become a new creature: a Christian of the heart instead of a believer of the sheer word. A spiritual rebirth had to be substituted for one's carnal birth. An active faith had to replace vices and sins with the guidance of the inner Christ.

With its overt dependence on mystics and religious enthusiasts such as Tauler and Weigel, Arndt's concept of a vivid piety aroused suspicion. It was intensively scrutinized, attacked, and defended by theologians during the $1620 \mathrm{~s}$ and was officially examined by the Jena theological faculty. ${ }^{20}$ But it was ultimately accepted as an attempt to deepen faith in accordance with Lutheranism. Later, the radical critic of the church Christian Hoburg used Arndt's piety of the heart in publications like Praxis Arndiana (1642) and Arndus redivivus (1677) as a contrast to the uninspired theological faith of the official church. ${ }^{21}$ Still, Arndt's radical call for an inner piety did not cause an openly contested affair, even if it was accompanied by a radical criticism of the church, as long as it remained a call to individual piety that did not lead to a spreading movement or-even worse - a movement that was organized.

The situation changed with the rising popularity of conventicles and the recognition of Spener as their intellectual father and principal defender. ${ }^{22}$ Now, Mentzer's view that the Pietist emphasis on praxis pietatis meant a regression to justification by works, the dismissal and denial of the authority, theology, and dogma of the church, as well as the overstressing of Luther's general priesthood of all believers and that it thus would lead first to the accepting of conventicles and then unavoidably to a Church schism, got new brisance. The Pietist affair at Leipzig University in 1689 triggered an official inquiry. The leader of the growing Pietist student movement, August Hermann Francke, reacted by sending a statement of defense to the Elector of Saxony, rejecting the charges of erroneous dogmata and the introduction of unacceptable innovations. The opponents should point out a single wrong tenet or bad example, if

20 Martin Brecht, 'Die Aufnahme von Arndts “Vier Bücher von wahrem Christentum,"' in: Frömmigkeit oder Theologie? Johann Arndt und die vier Bücher vom wahren Christentum, ed. Hans Otte and Hans Schneider (Göttingen, 2007), pp. 231-62.

21 Hans-Jürgen Schrader, “Misbräuche," “ärgerliches Christenthumb” und "Teutscher Krieg”: Christian Hoburgs kirchenkritischer Pazifismus unter Herzog Augusts prekärer Protektion,' in: Wirkungen des Pietismus im Fürstentum Wolfenbüttel: Studien und Quellen, ed. Dieter Merzbacher and Wolfgang Miersemann (Wiesbaden, 2015), pp. 47-87; Christian Hohburg, Praxis Arndiana: Das ist, Hertzens-Seufftzer uber die 4 Bücher wahren Christenthumbs (s.l., 1642); ibid., Drey geistreiche Tractätlein des sehl: Christian Hoburgs: I. Arndus Redivivus, Das ist: Arndischer Wegweiser zum Himmelreich.... (Frankfurt am Main, 1677).

22 Johannes Wallmann, Philipp Jakob Spener und die Anfänge des Pietismus, 2nd ed. (Tübingen, 1986), pp. 264-81; Mori, 'Conventicle Piety' (see above, n. 13). 
they could. The theological faculty answered with a comprehensive report and on 10 March 169 o the Saxon government prohibited conventicles. ${ }^{23}$

Four days later, the controversy deepened when conflicts about the so-called Hamburger Revers [Hamburg Proclamation] began. Orthodox members of the Hamburg ministry had drafted an official pledge to fight all innovations, which should be signed by all members. Unsurprisingly, the Pietist members of the ministry, who had organized conventicles, refused. The orthodox side asked four theological faculties for their expert opinions. The Pietist side answered with five theological responsa from high-ranking clergymen. A published defense by Johann Friedrich Mayer, the leader of the orthodox members of the Hamburg ministry, followed. It triggered the exchange of pamphlets between Spener and Mayer mentioned above. The Hamburger Revers proclaimed: "We confess unanimously with our personal signatures, that we adhere not only strictly to the confessional documents, but that we publicly deny and reject the recently appeared "pseudo-philosophers, Antiscripturarios, lax theologians, and other fanatics, particularly Jacob Böhme as well as chiliasm' and that we will not acknowledge their followers as brothers." ${ }^{24}$

As I emphasized before, theological dispute was a highly official procedure, considered essential to providing and securing the identity of the church. During the preliminary stages, the leading representatives of church governance, from the Elector and the theological faculties to the local ministries, defined the pitch, outlines, and general objects of the controversy, i.e., they defined its political framework. In the second step, the opposing camps translated the conflicting positions about the theological public sphere-how to defend church dogma properly-into a status controversiae, a controversial question which could be disputed; i.e., they defined the theological topic. The orthodox members of the Hamburg ministry formulated the question: Isn't an ecclesiastical authority allowed to bind its members to fight new heresies, due to its obligation to defend the true faith, as the Hamburg ministry had done with its Revers? The Pietist camp refashioned this question: Isn't an ecclesiastical authority exceeding its competence when it demands things and condemns teachings - matters not yet been decided in the confessional documents - without the resolution of the entire church? Within this range Mayer and Spener disputed the question of how to tackle "pseudo-philosophers, Antiscripturarios, lax theologians, and other fanatics, particularly Jacob

23 Gierl, Pietismus (see above, n. 3), pp. 217-22; Mori, 'Conventicle Piety' (see above, n. 13), pp. 206-7.

24 Vier Theologische Responsa, Auff einige Deß Hamburgischen Ministerii Fragen (s.l., 169o), preface. On the Hamburger Revers and the following upheavals in Hamburg, see Hermann Rückleben, Die Niederwerfung der hamburgischen Ratsgewalt: Kirchliche Bewegungen und bürgerliche Unruhen im ausgehenden 17. Jahrhundert (Hamburg, 1970). 
Böhme as well as chiliasm."25 Finally, Spener stated that only the entire church can formulate an obligatory confession of faith; chiliasm may be wrong but it is no fundamental error; the condemnation of Böhme presupposes the understanding and discussion of his entire work. In short: a quite open theological discussion should replace the restrictive defense of church dogma. The orthodox attacks had thus driven the Pietists, or at least Spener, to support an enlightened libertas philosophandi in matters of faith. Spener propagated individual freedom in religious matters in his Sieg der Wahrheit against Mayer in the autumn of 1692. In October, an official inquiry of Pietism was initiated in Halle, by now a hub of Pietist theologians.

Meanwhile, between 1690 and 1692 no fewer than forty radical adherents of a new practical piety claimed to have had divinely inspired visions. The Pietist movement threatened to run out of control and several governments reacted with proscriptions. By contrast, the Brandenburg government operated more ambiguously and with more sophistication in the Halle case: by electoral edict of December 1692 the doctrine of heartfelt piety as propagated by Francke and his fellow theologians was acknowledged to be orthodox and supportive of an active Christianity, useful for public order. But it prohibited the propagation and veneration of purported divine inspirations. A good ecclesiastical Pietism was contrasted with a sinister, radical variant. ${ }^{26}$

In the wake of the Brandenburg inquiry and edict, Johann Benedikt Carpzov, the influential leading theologian of Leipzig University, published anonymously his Unfug der Pietisten. Confronted with the Brandenburg acceptance of a moderate, ecclesiastical Pietism, Carpzov denounced Spener and his followers as a sect. According to ecclesiastical law, this implied the detection of a heterodox doctrine. The theologization of the controversy was underway. The Unfug der Pietisten outlined a "Systema theologiae pietisticae" consisting of twenty 'loci' regarding the 'principium cognoscendi,' 'finis,' 'subjectum,' and 'media' of theology-i.e., it employed classical analytical categories of Protestant systematic theology that reached back to Thomas Aquinas. ${ }^{27}$

Melanchthon's Loci communes rerum theologicorum seu Hypothyposes theologicae (1521), consisted of a system of loci, which were fundamental

\footnotetext{
25 Vier Theologische Responsa (see above, n. 23), preface.

26 Ryoko Mori, Begeisterung und Ernüchterung in christlicher Vollkommenheit: Pietistische Selbst- und Weltwahrnehmungen im ausgehenden 17.Jahrhundert (Tübingen, 2004), on the edict pp. 204-10.

27 Sung-Sup Lee, Wirklichsein und Gedachtsein: Die Theorie vom Sein des Gedachten bei Thomas von Aquin unter besonderer Berücksichtigung seiner Verbum-Lehre (Würzburg, 2006), pp. 51-63; Louis Berkhof, Systematic Theology: New Combined Edition (Grand Rapids, Mich., 1996), pp. 116-86.
} 
topics about God, sin, grace, sacraments, and the church. ${ }^{28}$ They constituted Lutheran systematic theology. The Unfug der Pietisten aligned itself with this tradition. Its "Locus I. de Scriptura Sacra" reads: the Pietists believe in a direct intuitive understanding of the Bible; "Locus II. De Visionibus \& Revelationibus peculiaribus": the Pietists hold visions to be the current revelations of God; "Locus III" rebuked Pietist beliefs "de beatitudine Chiliastica" and placed Spener's hope of better future times into this category. ${ }^{29} \mathrm{~A}$ couple of loci denounced the Pietist ambition to lead a completely pious life and their exclusion of adiaphora - morally indifferent things - from the social world. A couple of other loci expressed complaints about the self-empowerment of the Pietists in their claim of a spiritual priesthood of all and in their collegia pietatis. A third group of complaints addressed the Pietist's attacks on the authority of the Lutheran Church: their rejections of theology, the confessional documents, and uninspired priests. Reacting to the Brandenburg edict, Carpzov and the Leipzig orthodoxy drafted the outline of their ideas about acceptable piety and unacceptable, inner-church Pietism, respectively, with the "Systema theologiae pietisticae." 30

Replying to the thirteen Pietist rebuttals of the Unfug der Pietisten, the theological faculty of Wittenberg took the next step by further expanding and systematizing the "Systema." They excerpted Spener's writings-especially his pamphlets-and thus distilled his theological positions, assigning each of them to one of the twenty-one articles of the Augsburg Confession, the fundamental confession of faith of the Lutheran church. After an introductory fundamental discussion of Spener's convictions about theology, confessional doctrine, the status of Holy Scripture, and the confessional documents, the Wittenberg theologians concluded from each article of the Augsburg Confession the "sincere tenets," followed by a discussion of Spener's divergences from these tenets. ${ }^{31}$

In his answer, Spener further subdivided the resulting 284 sentences into single paragraphs. Pietism was here theologically enfolded, protocoled, and measured according to all aspects of Lutheran identity. Fusing legal, logical, and religious argumentation within the realm encompassing theology,

28 Philipp Melanchthon, Loci communes rerum theologicarum seu Hypotyposes theologicae (Wittenberg, 1521); see also Wilhelm Schmidt-Biggemann, 'Topik und Loci Communes: Melanchthons Traditionen,' in: Der Philosoph Melanchthon, ed. Günter Frank and Felix Mundt (Berlin, 2012), pp. 77-94; Irene Dingel, ed., Philip Melanchthon: Theologian in Classroom, Confession, and Controversy (Göttingen, 2012).

29 Ausführliche Beschreibung des Unfugs (see above, n. 14), pp. 27-8.

3o Ausführliche Beschreibung des Unfugs (see above, n. 14), p. 27.

31 See for example Christ-Lutherische Vorstellung (see above, n. 16), pp. 1-9. 
jurisprudence, and confessional order, the controversy constituted the idea of Pietist theology in all its contemporarily relevant dimensions. The Wittenberg theologians had analyzed the Pietist concepts of rebirth, perfectioning, and praxis pietatis with regard to the Lutheran confessional articles about God, justification, the sacraments (especially confession), penitence, grace, and good deeds. And Spener had rejected the accusations by commenting on them. The Wittenberg theologians had used the rhetoric of the Formula of Concord, a second linchpin of the confessional documents, to frame the single accusations: "We believe, teach, and confess...." Spener adopted the phrase in his reply: "I believe, confess, and teach...."32 The Wittenberg theologians constituted the orthodox Lutheran idea of Pietist theology. And Spener completed the Lutheran idea of Pietist theology from the Pietist perspective by explaining the interdependencies linking rebirth, perfectioning, and praxis pietatis on the one hand, and justification, penitence, grace, and good deeds on the other.

Two effects of the procedure are crucial. The core articles of Lutheran identity were submitted to a Pietist reinterpretation, and Pietism acquired a detailed Lutheran theological inventory. Arndt's demand for a heartfelt, allencompassing, active Christianity, in concert with the idea of a spiritual priesthood of all Christians, moved from the outskirts of pastoral care and individual belief into the core structure of the church-defining articles of the Lutheran church. Pietist piety merged with the confessional standards of the church. The rules, procedures, and conventions of the theological dispute ensured the production and steady transformation of practiced piety into a comprehensive theology, which answered to all the central aspects of the Lutheran churchfrom the concept of God and Christ to the use of sacraments.

Including the supporters' as well as the opponents' side theological controversies led to the realization of a systematic idea about religious stances not for the sake of the idea, but as a practical tool to organize church life. Spener's position was that the Pietist convictions not only matched but vitalized the Lutheran articles of faith. Keeping in mind the practical sense of the efforts to elaborate a theology of Pietism, it becomes understandable why it was the answers to the practical consequences- the use of the sacraments, especially confession, absolution, remorse, penance, and divine mercy - and not so much to the abstract concepts like God and justification, that troubled Spener in his attempt to reconcile his positions with the Lutheran doctrines. He admitted that the Church practice of private confession and absolution were not satisfactory. ${ }^{33}$ 
These were exactly the points which led - not by chance - to extensive controversies between 1697 and 1710: the Berlin dispute about the confessional and the 'terministic' controversy. In Berlin in 1697 the Pietist deacon Johann Kaspar Schade rejected private confession for reasons of conscience. ${ }^{34}$ In 1698, Johann Georg Böse, another Pietist theologian, published an account of his conviction that God had 'terminated' his divine mercy in order to exclude from his considerations the undiscerning sinner's last-minute remorse before dying. ${ }^{35}$ As the sheer extension of these conflicts already shows, the communicational execution of the theological controversy encompassed the concept of Pietism down to its last practical — that is, ecclesiastical—detail.

A central element in this creation of theological ideas and concepts out of communicational procedures was a steady discussion about the rules and obligations the opponents should respect in order to discuss their points in a proper and significant manner. One way to ensure that these norms would be followed was to sue the adversary before the local authorities; another way was to publicly discuss the formal rules and procedures of theological controversies, as in the case of the Hamburger Revers. A third option was to change the inner technical procedures used to obtain, measure, and assess theological truth.

This latter way was what Spener tried when August Pfeiffer attacked his 'hope of better future times.'36 Pfeiffer invoked the Second Coming of Christ. Luke 18,8 reads: "Nevertheless, when the Son of Man comes, will he find faith on the earth?" Pfeiffer took this passage as proof that the world would not be a better place at the end of time and that God had ordered it that way. Spener retorted that although Pfeiffer's interpretation could be true, that there was another equally possible reading. If Christ came right now, he would not be pleased, finding the world still abounding in unbelief. Spener concluded that if all pertinent scriptural passages are read and compared carefully, everybody

34 Claudia Drese, 'Der Berliner Beichtstuhlstreit oder Philipp Jakob Spener zwischen allen Stühlen,' Pietismus und Neuzeit 31 (2005), 60-97; Helmut Obst, Der Berliner Beichtstuhlstreit: Die Kritik des Pietismus an der Beichtpraxis der lutherischen Orthodoxie (Witten, 1972).

35 Andreas Gössner, Der terministische Streit: Vorgeschichte, Verlauf und Bedeutung eines theologischen Konflikts an der Wende vom 17. zum 18. Jahrhundert (Tübingen, 2011).

36 Philipp Jakob Spener, Behauptung Der Hoffnung künffiger Besserer Zeiten / In Rettung Des ins gemein gegen dieselbe unrecht angeführten Spruchs Luc. XIIX, v. 8 (Frankfurt am Main, 1693); August Pfeiffer, Gerechte Sache / Welche wider Tit. Hn. Phil. Jac. Spenern, verthädiget / Und dabey gründlich/ deutlich und glimpflich erwiesen wird / Daß die gemeine Auslegung der Evangel. Theologorum über den Spruch Luc. XVIII.8.... annoch feste stehe (Lübeck, 1695); see also Heike Krauter-Dierolf, Die Eschatologie Philipp Jakob Speners: Der Streit mit der lutherischen Orthodoxie um die "Hoffnung besserer Zeiten" (Tübingen, 2005), pp. $145^{-281 .}$ 
should have the freedom to understand the divine truth according to his conscience. ${ }^{37}$ No human authority had the right to prescribe an ultimate biblical exegesis.

During the same period, beginning in January 1695, Francke published a monthly journal, the Observationes Biblicae oder Anmerckungen über einige Oerter H. Schrifft Darinnen die Teutsche Übersetzung des Sel. Lutheri gegen den Original-Text gehalten und bescheidentlich gezeiget wird [Observationes Biblicae or notes on several Bible passages, comparing Luther's translation with the original text, in which it is humbly shown how to discern the proper meaning of the text]. ${ }^{38}$ Unsurprisingly, the journal prompted many refutations. ${ }^{39}$ Yet it was not the contents but rather the medial form of Francke's enterprise which upset his opponents. That he published his critique in German and especially in periodical form was a "damnable Satanic ruse."40 Francke's 'Satanic ruse' actually furthered the change in media from disputations to journals as a means to defend and debate theological doctrine. The journal provoked the emergence of orthodox Anti-Pietist polemical journals. ${ }^{41}$ These failed. But in 1701, the Unschuldige Nachrichten von Alten und Neuen Theologischen Sachen [Innocent Reports of Old and New Theological Subjects]—edited by Valentin Ernst Löscher (1673-1749), a leading opponent

37 Martin Gierl, ‘Befleckte Empfängnis: Pietistische Hermeneutik, Indifferentismus, Eklektik und die Konsolidierung pietistischer, orthodoxer und frühaufklärerischer Ansprüche und Ideen,' in: Strukturen der deutschen Frühaufklärung 1680-1720, ed. Hans Erich Bödeker (Göttingen, 2008), pp. 119-46, there 126-9.

38 'Observationes Biblicae oder Anmerckungen über einige Oerter H. Schrifft Darinnen die Teutsche Übersetzung des Sel. Lutheri gegen den Original-Text gehalten und bescheidentlich gezeiget wird Wo man dem eigentlichen Wort-Verstande näher kommen könne,' in: August Hermann Francke: Schriften zur biblischen Hermeneutik I, ed. Erhard Peschke (Berlin, 2003), pp. 361-640.

39 For the refutations see Johann Georg Walch, Historische ... Einleitung in die ReligionsStreitigkeiten, welche sonderlich außerhalb der Evangelisch-Lutherischen Kirche entstanden, 3rd. ed., 5 vols. (Jena, 1733), 1: 731-6; Kurt Aland, 'Bibel und Bibeltext bei August Hermann Francke und Johann Albrecht Bengel,' in: Pietismus und Bibel, ed. Kurt Aland (Witten, 1970), pp. 89-147, there pp. 102, 109-19; 'Observationes' (see above, n. 37), pp. 362-3. On the 'shocking' nature of the journal in comparison with the traditional correspondence see also Anne Goldgar, Impolite Learning: Conduct and Community in the Republic of Letters, 1680-1750 (New Haven, 1995), pp. 44-73.

40 Johann Friedrich Mayer, Anweisung Zum Recht Lutherischen Gebrauch Des Heiligen Psalter-Buchs / Sammt einer Vorrede An alle Studiosos Theologiae Ihro Königl. Majestät von Schweden Landes-Kinder in Teutschland Sich von Herrn M. Aug. Hermann. Franckens P.P. und Pastoris Glauch. Oberservationibus Biblicis nicht verleiten zu lassen (Hamburg, 1695), § 17.

41 Johann Friedrich Mayer, Herr D. Spener wo ist sein Sieg? Das ist Offenbahre Niederlage Hn. D. Philipp Jacob Speners ... (Hamburg, 1696); Friedrich Christian Bücher, Menses Pietistici (Wittenberg, 1705). 
of Pietism - appeared on the market: a learned review journal in the new style, yet having a boldly orthodox Lutheran bias. It would become the central orthodox Lutheran organ until 1761. Löscher emphasized in the preface to the journal that truth could no longer be asserted through disputations and the exchange of pamphlets. Rather, one had to be quick-witted, succinct, general, up-to-date, and - not least via the use of the German language-accommodating to the audience, just as Francke had demonstrated with his journal. ${ }^{42}$

Francke's Observationes were innovative in terms of not only the media format but also its use of Biblical studies and hermeneutics. After citing the original Greek text and Luther's translation, Francke presented his critique: Luther's translation was not verbatim, he had omitted words, and his grasp of the meaning of words was flawed. In short, Francke, who compared this translation with several other Bible editions, criticized Luther for philological imprecision..$^{43}$ Remarkably enough, improvement and research - central values of the emerging Enlightenment-popped up in this regard: they would be necessary for the "interpretation of the Holy Script, that one investigates continuously and that there was a steady increase in Christianity."44 Like Spener, Francke used critique to connect biblical exegesis with a solid but individually constructed sense of scriptural meaning. The next step of the Halle-led preoccupation with hermeneutics would see Siegmund Jakob Baumgarten asking about the demonstrability of a biblical interpretation, and his pupil Johann Salomo Semler about its historicity. ${ }^{45}$

\section{$4 \quad$ How Theological Controversy Became Ecclesiastical History}

From the turn of the eighteenth century onwards, the controversy entered its third phase: historicization. Historical perspective was a regular element in theological controversy. To keep sight of the overall picture of the multifaceted controversy, there were controversy-specific media, the so-called synoptic pamphlets (Generalschriften), which summarized the controversy from the

42 Unschuldige Nachrichten von Alten und Neuen Theologischen Sachen (Leipzig, 1701-19 [Cont.: Fortgesetzte Sammlung von alten und neuen theologischen Sachen (Leipzig, 172050)]; Gierl, Pietismus (see above, n. 3), pp. 400-13.

43 'Observationes' (see above, n. 37), pp. 363, 646-8.

44 "Auslegung der heiligen Schrifft immer weiter nachforsche / und auch diesfals ein stetiges Wachsthum in der Christenheit sey, 'Observationes' (see above, n. 37), p. 612.

45 Ulrich Barth, Aufgeklärter Protestantismus (Tübingen, 2004), pp. 169-98. On Francke's biblical hermeneutics, see Erhard Peschke, Studien zur Theologie August Hermann Franckes, 2 vols. (Berlin, 1966), 2: 13-126; idem, Bekehrung und Reform: Ansatz und Wurzeln der Theologie August Hermann Franckes (Bielefeld, 1977), pp. 59-88. 
orthodox perspective. The longer the dispute lasted, the more these pamphlets became historical documents. Meanwhile, the Pietist side succeeded in institutionalizing itself in Halle. Pietists held many high offices in the church. The orthodox camp was on the wane. A turnaround occurred in many respects. In the early 1730s, Johann Georg Walch, a moderate Pietist theologian, published a five-volume work on the Pietist controversy, still regarded as the first comprehensive historical description of Pietism. ${ }^{46}$

Walch adopted the organizational scheme of the last great synoptic pamphlet, Schelwig's Synopsis. ${ }^{47}$ Aligning his presentation with the Melanchthonian tradition of systematic theology, as the Mischief and the Wittenberg faculty had done in the 169os, Schelwig structured his overview of the Pietist controversy by linking the theological subjects of the controversy with the fundamental topics of Lutheranism. Melanchthon's fundamental topics of Lutheran theology, which sketched out the Augsburg Confession, had been "Deus, Unus, Trinus, Creatio, Homo, Hominis vires, Peccatum, Fructus peccati, Vicia, Poenae, Lex, Promissiones, Instauratio per Christum, Gratia, Gratiae fructus, Fides, Spes, Caritas, Praedestinatio, Signa sacramentalia, Hominum status, Magistratus, Episcopi, Condemnatio, Beatitudo."48 Organizing the issues of the Pietist controversy, Schelwig adopted this systematic grid of Lutheran theology in the composition of his own work. The outcome was a complete theology of Pietist tenets: "De Theologia, De Religione, De Scriptura, De Enthusiasmo, De Libris Symbolicis, De Deo Trinuno, De Jesu Christo, De Spiritu Sancto, De Creatione, De Providentia, De Homine, De Imagine Dei, De Peccato, De Libero Arbitrio, De Gratia Dei, De Electione, De Vocatione, De Illuminatione, De Regeneratione, De Justificatione et Fide, De Unione Spirituali, De Sanctificatione et Bonis Operis, De Poenitentia, De Lege et Evangelio, De Baptismo, De Eucharistia, De Ecclesia, De Hierarchia Ecclesiastica, De Hierarchia Politica, De Hierarchia Oeconomica, De Re Scholastica, De Cultu Dei, De Libertate Christiana, De Novissimis, De Chiliasmo, De Haeresibus aliis. ${ }^{49}$ Walch used the synoptic pamphlets of the controversy to obtain the material for his history of Pietism, and his description of the controversy's contents were ordered according to Schelwig's arrangement. Only the topics 'enthusiasm,' 'chiliasm,' and 'heresy'

46 On Walch's Historische Einleitung (see above, n. 38), see: Gierl, Pietismus (see above, n. 3), pp. 248-53; Johannes Wallmann, Der Pietismus [Die Kirche in ihrer Geschichte: Ein Handbuch, ed. Bernd Moeller, vol. 4: O1], (Göttingen, 1990), p. 2.

Samuel Schelwig, Synopsis controversiarum, sub pietatis praetextu motarum, 3rd ed. [1st ed. 1701] (Dantzig, 1705).

48 Melanchthon, Loci (see above, n. 27), introductory letter to Tilman Plettener.

49 Schelwig, Synopsis (see above, n. 46), treated articles. 
are missing in Walch's narration of Pietist theology, because, as Walch stated, these issues did not belong to Pietism. ${ }^{50}$

Pietist historiography became the continuation of the controversy by other means and under different conditions. The general shift from the defense of dogma toward a permanent witness of faith was accompanied, quite remarkably, by a parallel shift from disputation to persuasion, from detailed and comprehensive refutation to permanent and systematic publication, hermeneutically from the detection of the deviant to the propagation of the coherent, in terms of media from pamphlets to journals and compendia. Johann Georg Walch's Historische Einleitung in die Religionsstreitigkeiten der evangelischen Kirche [Historical Introduction to the Religious Controversies of the Evangelical Church] is a perfect example of the transition from controversy to historiography. One can refer to Arnold's famous anti-orthodox Unpartheyische Kirchen- und Ketzerhistorie [Impartial History of the Church and Heretics] from 1699 as well, which some now regard as the beginning of modern ecclesiastical history. ${ }^{51}$

Syllogistic controversial argumentation and therefore the work of one group against another group became historical narration and thus the stated opinion of a single author distinguished by proven scholarship. On the old stage theologians had discussed cases denouncing certain beliefs, behavior, and incidents belonging to a person or group with the intent of completeness and absolute refutation. The historians took over all these elements on the new scene with its new rules of play. Ecclesiastical history maintained the complete treatment of its subject, exactly as had been done in theological controversy. Consequently, Walch's five volumes consist of two volumes of description of the Pietist debate, followed by a highly repetitive volume reordering exactly the same matters according to the points of the discussion, followed by two supplementing volumes, which Walch wrote to complete and to update the narrative. Arnold based his Ketzerhistorie, to give another example, on the biographies of individuals. He subdivided each biographical unit into a description

5o Walch, Historische Einleitung (see above, n. 38), 2: 75 .

51 Gottfried Arnold, Unpartheyische Kirchen- und Ketzerhistorie, Vom Anfang des Neuen Testaments biß auf das Jahr Christi 1688, 2 vols. (Leipzig, 1699); see Hans Schneider, 'Der radikale Pietismus im 17. Jahrhundert,' in: Geschichte des Pietismus, vol. 1, ed. Martin Brecht (Göttingen, 1993), pp. 391-437, there pp. 410-15; Frank Carl Roberts, Gottfried Arnold as a Historian of Christianity: A Reappraisal of the Unparteiische Kirchen- und Ketzerhistorie (Nashville, 1973); Katharina Greschat, 'Gottfried Arnolds 'Unparteiische Kirchen- und Ketzerhistorie' von 1699/1700 im Kontext seiner spiritualistischen Kirchenkritik,' Zeitschrift für Kirchengeschichte 116 (2005), 46-62; Markus Sturm, "daß man wol an fremden und vorigen schaden klug werden möchte": Aspekte einer pragmatischen Historiographie bei Gottfried Arnold (Vienna, 2007). 
of the teachings held by this person and a narration of their persecution. Along these lines he unfolded the history of the church. For Walch and for Arnold history still obeyed the logic of cases. Ideas were stressed not for their own sake but as events for teaching and therefore as a certain kind of action which caused certain effects in the network of events that makes up history.

The aim of the old theological controversies was to re-establish consensus through a process of regulated discussion. The basic idea was to define and ban errors. Ecclesiastical history, on the other hand, was based on narration. Instead of the regulated bipolar conflict within a group of combatants, revolving around an increasingly extended core of a syllogistic status controversiae that, step by step, made the whole process controllable, historiography provided comprehensive narration and therefore the personal opinions of individual authors, whose statements had to be legitimized within the framework of the discipline. The basic idea now was to safeguard confessional identity through a perpetual, and in the long run infallible, process of improving knowledge. Control shifted toward the possession of an ever more detailed knowledge about the subjects of the field and the facilities to disseminate it. The unfolding literary market and its media and institutions-libraries, textbooks, journals, universities - were on the threshold of becoming the players in a new game with new rules, but with the traditional aim of safeguarding belief and identifying deviation.

Historiography had inherited the twofold focus on events and ideas as well as the obligation of completeness. The old disputant would have stated: A is wrong, because of $\mathrm{B}$. And his counterpart would then have answered $\mathrm{A}$ is right, because $B$ is wrong, because of $C$, and so on. Walch would now report the event in the following manner: There was a conflict in Hamburg. This and that happened. Then the ministry published a pamphlet offending Spener by maintaining something, which Spener answered by stating this and that. This and that general topic was discussed, with some points of B turning out to be not completely wrong though the main aspects of Spener's $C$ represented the most convincing position. ${ }^{52}$

In the old theological controversies the pamphlets had been the weapons and instruments of the dispute. They had been the acts of the event. Now cited for reasons of evidence, they were being dispatched to the footnotes and became references in the hands of the author, who filled the space above with his individual but institutionally as well as methodically authorized opinion as a voice in the chorus of ecclesiastical history. 
Remarkably — but not surprisingly for those who acknowledge that communication and with it the constitution of ideas rests upon interacting correspondences between cultural institutions and socially oriented media-the transition from dispute to historiography took place as an evolutionary process. Whereas Francke and Löscher had mutated pamphlets into journals, Walch, Arnold, and others transformed and embedded controversy into historiography. For Arnold — as for Walch and later accounts—church history consisted basically of the controversies of the past as they related to the constituents of religious communities. In this sense they resembled the former controversialists, especially the writers of synoptic pamphlets, who recounted the course of the controversy in order to prove the emergence of a sect. But Arnold's and Walch's narrations inverted the power relations inherent in controversy, so that what had been opponents and sects became religious groups-'parties,' Arnold would call them. ${ }^{53}$

Doctrinal controversies consisted in the fights between adversaries about specific dogma. They constituted official events. Walch's and Arnold's accounts, however, moved the individual innovator and his convictions into the forefront of a subjective description. Rebuttals and defenses of these convictions became elements of a process of reception. What the former generation had done by way of the official documentation of deviation mutated into an individual history of ideas, which now grounded the ecclesiastical history quasi-impartially by characterizing and then stringing together the different religious groups then in existence. Walch used that model for the EvangelicalLutheran church, telling not only the story of the Pietist controversy but first describing systematically the disputes among Protestants and the resulting religious groups of the seventeenth century. Like Walch, Arnold contextualized the controversies in order to transform polemics into historiography.

With its double-sided character-at once a pamphlet and a comprehensive historiography-Arnold's Ketzerhistorie is probably the most impressive example of the ongoing evolution. On the one hand, Arnold introduced his work by raising systematically no fewer than 180 critical questions about Ketzermacherei (the making of heretics), heretics themselves, how to treat them, and heresies in general, directly succeeded by his answers to these "quaestiones factorum or loci communes" respecting "problemata or so-called articles," as he called them. ${ }^{54}$ Arnold fortified his position with quotations taken from a wide range of prominent Lutheran theologians, especially those (pts. 23, 28), pp. 29, 67, etc. 
of the seventeenth century. Around two thousand folio pages followed, in which Arnold developed his argument that the history of the official church consisted of the making of heretics and that these heretics were the true followers of Christ. He built his case by describing the conflicts, giving biographical and bibliographical outlines, citing theses and counter-theses, and quoting edicts and other sources. In short, Arnold defined the status controversiae, confirmed his position with testimonies, and proved his point by providing a comprehensive description of the species facti. Seen from this perspective, Arnold's Ketzerhistorie is nothing but a huge pamphlet in the common form and, as such, an endeavor and coup de main within the old praxis of theological controversies.

Yet Arnold packed the features of classical disputations into the classical formal elements of contemporary historiography. Following the patterns of chronicles - the still dominant historiographical format-and more specifically the method of the famous Protestant church history Magdeburg Centuries, Arnold divided his material into 'books,' each covering one hundred years, numbering seventeen in all from the beginning until 1688. Each book contains chapters on the outer and the inner conditions of the church, followed by description of the ongoing contentions. The first volume of Arnold's work covers the time until the Reformation, with volume two treating the Reformation age, but now in much greater detail. Arndt and Spener appear, mentioned in the general introduction on the Lutheran controversies of the seventeenth century in book 17, chapters 5 and 6, quite cleverly taken out of the series. Arnold used them as commentators and testimonies for his account of ecclesiastical history as a history of Ketzermacherei. Arnold addresses the Lutheran as well as the Reformed and the Roman Catholic churches, their main factions like the Socinians, Arminians, Syncretists, or Jansenists, and last but not least, contested innovators and individualists like Weigel and Böhme.

Temporal completeness with regard to chronology and material completeness with regard to the subject matter supplanted the former demand for a complete refutation of the opponents' arguments. Historical consistency was now a substitute for the logical consistency of the syllogistic disputes. In each book and each chapter, Arnold presented the diverse aspects of his subjects in paragraphs, each concluded by a bibliography. Bibliographical references here took the place of references to the topoi of the systematic theology. The presentation of arguments developed step by step into a constructed narrative. Arnold effected a turn from the negotiation of theological truth whose terms were bounded by official disputes toward an allegedly impartial historiography. Not only was this a conscious strategy, it was in fact the deliberate aim of his Unpartheyische Ketzerhistorie. Addressing the reader directly, Arnold stated at the beginning that his work would treat central Christian teaching, which 
should not be left to "vulgar systematic scholastic theology" but rather be decided from "historical fundaments." ${ }^{55}$ Already in his work's title, Arnold contrasted his aspirations for an impartial history against the aggressive partiality, and in fact party-making impetus, of doctrinal controversies. No wonder that the Ketzerhistorie provoked an extensive debate about Arnold's own impartiality and the necessity as well as the possibility of impartiality in historical writings. ${ }^{56}$ Core values of Enlightened historiography were on their way.

The further evolution from disputation to history may be demonstrated by the universal chronicle Eröffneter Schauplatz der Allgemeinen Welt-Geschichte des achtzehenden Jahrhunderts [Opened Stage of the General World-History of the Eighteenth Century]. ${ }^{57}$ This popular compendium was published in 1744 by Johann Heinrich Zedler, who between 1732 and 1754 also edited the largest German encyclopedia project of the Enlightenment, the Grosses vollständiges Universal-Lexicon [Great complete Universal Dictionary], often simply called 'the Zedler', in 64 volumes. ${ }^{58}$ The Eröffneter Schauplatz was editorially supervised by Carl Günther Ludovici, a Leipzig professor and member of the Berlin Academy of Sciences, who also supervised the Zedler from volume 19 onward and who is still known for his comprehensive biographies of Wolff and Leibniz. Zedler included the chronicle as volume 13 in his historical series Allgemeine Staats-, Kriegs-, Kirchen- und Gelehrten-Chronicke, In welcher alle geist- und weltliche Denckwürdigkeiten und Geschichte, so sich vom Anfang der Welt bis auf unsere Zeit zugetragen ... ans Licht gestellet [General State-, War-, Church-, and Scholarly Chronicle, in which all spiritual as well as secular memorabilia, which happened from the beginning of the world until our time, ... are compiled], which was published from 1733 to 1754 in 21 volumes. ${ }^{59}$

55 Arnold, Unpartheyische Ketzerhistorie (see above, n. 50), 1: 1.

$5^{6}$ See Walch, Historische Einleitung (see above, n. 38), 2: 693-713; Friedrich Wilhelm Kantzenbach, 'Theologisch-soziologische Motive im Widerstand gegen Gottfried Arnold,' Jahrbuch der Hessischen Kirchengeschichtlichen Vereinigung 24 (1973), 33-51; Irmfried Martin, Der Kampf um Gottfried Arnolds Unpartheyische Kirchen- und KetzerHistorie (Heidelberg, 1973), pp. 11-21; Jürgen Büchsel, 'Gottfried Arnolds Verteidigung der Unparteiischen Kirchen- und Ketzerhistorie, dargestellt anhand seines Briefwechsels mit Hofrat Tobias Pfanner, in: Der radikale Pietismus, ed. Wolfgang Breul et al. (Göttingen, 2010), pp. 85-104; Ernst Berneburg, 'Einige Gesichtspunkte und Fragen zur Wirkung der Unparteiischen Kirchen- und Ketzerhistorie,' in: Gottfried Arnold (1666-1714), ed. Dietrich Blaufuß and Friedrich Niewöhner (Wiesbaden, 1995), pp. 21-32.

57 Carl Günther Ludovici, Eröffneter Schauplatz der Allgemeinen Welt-Geschichte des achtzehenden Jahrhunderts ... (Leipzig, 1744).

$5^{8}$ Grosses vollständiges Universal-Lexicon Aller Wissenschafften und Künste ... (Leipzig, Halle, 1732-54).

59 Allgemeine Staats-, Kriegs-, Kirchen- und Gelehrten-Chronicke, In welcher alle geist- und weltliche Denckwürdigkeiten und Geschichte, so sich vom Anfang der Welt bis auf unsere Zeit zugetragen ... ans Licht gestellet. 21 vols. (Leipzig, 1733-54). 
Taken together, Zedler's encyclopedia and chronicles promised to provide a complete inventory of all things that existed and had ever existed in the world. As the boastful titles of these publications indicate, they are directed to a wider audience. The representation of church history given by the Eröffneter Schauplatz der Allgemeinen Welt-Geschichte drives to its formal extreme the transformation of doctrinal disputes into historiography, as Walch and Arnold had pursued it. On the one hand, Church history still consists of the ongoing controversies. This is evident from the table of contents of "Chapter II: Of the Lutheran Church-Histories":

I. The history of the Pietist Controversies are told ... as at Gotha; II. As well as at Halle in Saxony. III. Princely-Brunswick-Wolffenbüttel as well as the Ducal-Celleian edict contra the Pietists. IV. As well as the PrincelySaxonian-Merseburgian edict contra the Pietists. v. Royal-Swedish Schwartzburg-Arnstädtian and Meynungian edict. VI. Pietist controversies at Danzig. viI. Schelwig's controversy with Spener on some doctrines of the so-called Pietisterey. viII. On occasion of the Pietist controversy the question rose: how to assess Jakob Böhme and his writings? Ix. The entire theological faculty of Wittenberg declares itself publicly against Dr. Spener. X. Spener's controversies with Carpzov, Mayer and Alberti. XI. Continuation of the Pietist controversies at Danzig....60

And so on. All together the Eröffneter Schauplatz der Allgemeinen WeltGeschichte divides Lutheran church history of the years 1701-10 into 176 conflicts.

On the other hand, the personal and local controversies are transformed into the building blocks of a historical narration. The Eröffneter Schauplatz offers them in yearly installments, registering the incidents and publications of the controversies year after year in the chronological order. The chronicle pretends to be a complete overview of the events as they had occurred, and attempts completeness with regard to the presented subjects. It addresses not only the Catholic, Reformed, and Lutheran churches but also includes sections about the Greek Orthodox church, the 'Mohammedans', the 'contemporary Jews,' and the 'newer paganism' as reported by the unfolding Protestant missionary activities. ${ }^{61}$

The new historical completeness, which swallowed up the theological controversies, including and absorbing the conflicts, pamphlets, and argumentations side by side with the depictions of political and scholarly history, rested

6o Ludovici, Eröffneter Schauplatz (see above, n. 56), p. 103.

61 Ludovici, Eröffneter Schauplatz (see above, n. 56), pp. 328, 377, 383, 412. 
upon compilation. It was built upon the new Enlightened media, especially the continuously updated handbooks and journals, which provided access to a steadily protocoled and comprehensively disseminated stock of information and facts. The Eröffneter Schauplatz der Allgemeinen Welt-Geschichte became possible because Walch's Historische Einleitung in die Religionsstreitigkeiten and Löscher's Unschuldige Nachrichten Alter und Neuer theologischer Sachen had transformed the old pamphlets and their form of argumentation by bringing them into new media formats. The Eröffneter Schauplatz cites Walch's Historische Einleitung in die Religionsstreitigkeiten fourteen times, the Unschuldige Nachrichten more than forty times. ${ }^{62}$ As the institutions and officeholders of the old Lutheran Church stood behind the old procedures of theological controversies along with their official character and impact, the members and participants of the Republic of Letters, now finally come into its own, modern in its self-perception and later recognized as 'Enlightened,' instrumentalized the new media formats to organize and remodel knowledge according to their own demands and purposes. Using new instruments to process statements and facts implied that there were new rules to provide and tag information as knowledge. Theological controversy was sucked into the upand-coming public sphere and its preferred media. It had to follow the rules that were now valid on the new, widened pitch. The ways to say and defend the theological truth were remodeled alongside the possibilities of the new narrative forms according to the changed audiences, markets, interests, necessities, and applications.

Ideas are the outcome of practice. They possess forms and invite resistance, are fixed or developed, become acknowledged or forgotten, because they are perceived and received. Ideas are and exist as integral elements of communication systems fulfilling certain purposes. A horse is a horse-but it makes an essential difference whether the horse stands in a meadow or before an equine butcher. Theological ideas remained theological ideas but, having once been tools to separate orthodoxy from heterodoxy, they were now elements of the Enlightened reprocessing of knowledge. Shifting from orthodox to Enlightened knowledge, theological ideas became part of new negotiations of knowledge. Whether an idea was heterodox or not became secondary. These ideas' primary function was now to share in the Enlightenment's moral economy of impartiality, actuality, improvement, perfection, reasonability, and completeness. The function of theological controversies had been to erase heterodoxies. The purpose of the Enlightened media was to provide access to the entirety of ideas, in order to keep them at hand for further use.

62 Figures according to Google Books. 